Volume and Issues Obtainable at Center for Sustainability Research and Consultancy
Journal of Accounting and Finance in Emerging Economies
ISSN: 2519-0318 ISSN (E) 2518-8488
Volume 6: Issue 4 December 2020
CSRᄃ
Jofit

\title{
Comparative Analysis of Effective Project Governance Practices and Benefit Realization Management for the Successful Execution of Projects in NGO Industry
}

\author{
${ }^{1}$ Shahid Iqbal, ${ }^{2}$ Khalid Rehman, ${ }^{3}$ Waheed Asghar, ${ }^{4}$ Syed Arslan Haider \\ ${ }^{1}$ Assistant Professor, Management Studies Department,Bahria University, Islamabad Campus, Pakistan, \\ siqbal.buic@bahria.edu.pk \\ ${ }^{2}$ Lecturer, Institute of Business Administration,Gomal University, Dera Ismail Khan, Pakistan, \\ khalidrehman@gu.edu.pk
}

${ }^{3}$ Director in Technical Education and Vocational Training Authority, Government of the Punjab, Lahore, Pakistan, director.at@tevta.gop.pk

${ }^{4} \mathrm{PhD}$ Scholar, Department of Management, Sunway University Business School (SUBS), Sunway University, Malaysia, haidershah24@gmail.com

\begin{tabular}{|c|c|}
\hline \multicolumn{2}{|l|}{ ARTICLE DETAILS } \\
\hline History & Purpose: This study has examined the influence/control of effective project \\
\hline Revised format: November 2020 & governance practices on the accomplishments of the different projects \\
\hline Available Online: December & those were carried out by the Non-Government Organizations (NGO) \\
\hline 2020 & sector in Pakistan. This study has also analyzed the significance of benefits \\
\hline Keywords & realization management as moderation between project governance and \\
\hline Effective Project Governance; & project success in order to achieve the organizational strategic goals and \\
\hline Project Success; Benefits & $\begin{array}{l}\text { objectives. } \\
\text { Design/Methodology/Approach: Ouantitative research methodology has }\end{array}$ \\
\hline $\begin{array}{l}\text { Realization Management; } \text { Non- } \\
\text { Governmental Organizations. }\end{array}$ & 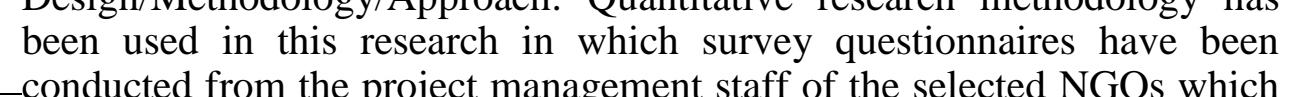 \\
\hline JEL Classification: & have their head-offices in twins cities Rawalpindi and Islamabad. A total \\
\hline M48, M49 & $\begin{array}{l}\text { of } 305 \text { responses as per the simple random sampling of the project } \\
\text { management staff of selected NGOs have been used to draw the results of } \\
\text { this research using Smartpls software version } 3 \text { to analyze the data in order } \\
\text { to prove the hypothesis of this research. }\end{array}$ \\
\hline & $\begin{array}{l}\text { Findings: After through examining/securitization of the data, it was clearly } \\
\text { seen that there were positive/momentous effects on the efficiency of the } \\
\text { projects, benefits of the organizations, impact of the projects \& its future } \\
\text { perspective to be more successful. Moreover, the moderating effect of } \\
\text { benefits realization management in the relation between project governance } \\
\text { and organizational benefits, project impact, project efficiency also } \\
\text { stakeholder satisfaction is positive and significant. However, benefits } \\
\text { realization management insignificantly moderate relation between project } \\
\text { governance and future potential. }\end{array}$ \\
\hline
\end{tabular}
NonCommercial 4.0

Corresponding author's email address: siqbal.buic@ bahria.edu.pk

Recommended citation: Iqbal, S., Rehman, K., Asghar, W. \& Haider, S. A. (2020). Comparative Analysis of Effective Project Governance Practices and Benefit Realization Management for the Successful Execution of Projects in NGO Industry. Journal of Accounting and Finance in Emerging Economies, 6(4), 941-952 


\section{Introduction}

It had been seen that there is a wide variance in understanding and defining EPG i.e. "Effective Project Governance" which had been actually based on the setting of its technical/technological background \& moreover on its researchbased pasture of so many researchers/authors (Ul Musawir et al., 2017).Zwikael \& Smyrk (2015) described the EPG as using of some specific systems, authority of the structures \& having different project management processes for the allocation of resources (both physical \& materialistic) while coordinating the activities/milestones in different projects.On the other side/perspective the Ul Musawir, Abd-Karim \& Mohd-Danuri (2020) explained that the effective project governance also exists having the exclusive objective for the achievement of requisite goals of the organizations already planned/fixed within the framework/model. Furthermore, success of project is understood as the attainment of a certain order of subjective and objectives calculations, demonstrated in success criteria of a project that is calculated after the project is completed (Mahmood et al., 2017). As per Santos et al. (2020) the success criteria of a project could include several variables on the basis of which the project success is measured, this research has adapted the same model presented by him, who had examined the past forty (40) years research literature in this field of knowledge related to the best success/accomplishment criteria for the creation of a unified model for measuring project success (Latif et al., 2020).

The model proposes an equilibrium among soft and hard elements and quantifies twenty-five variables of success criteria arranged in five dimensions, researcher has adapted this five-dimension criteria to measure the effect of the EPG on the success of the non-governmental organizations(NGO) sector development projects in Pakistan as a gap found in the literature by the researcher. Researcher has also analyzed the role of benefits realization management (BRM) as a moderatorin between EPG and project success (Stretton, 2020). As per theSvejvig \& Schlichter(2020)benefits realization management (BRM) is a "set of different project processes which produce the authenticity/confirmation that the different Projects/programs/portfolios implant the requisite necessities of project and business strategies \& guidelines into different business practices for the creation of worth of the projects in a significant/remarkable way.

A good amount of researches have been conducted on the association among the governance of project, performance of project management and success of project, but according to Mir \&Pinington (2014) it has been determined that project management performance doesn't entirely justifies the divergence in the project success as there are several other external factors then the Iron Triangle (Scope, cost and time) that explain the variation in the success of a project. Therefore, more researches are to be conducted to measure the influence of external factors on project success which could create an impact on project success (Breese et al., 2015). Researchers indeed have begun to expend the extent of viable factors of success to focus on the impact of them on success of the projects and one of these factors is considered to be EPG, that has gained much recognition since the year 2005 (Tomo et al., 2020). As per AMP (2015) \& PMI (2016) the failures of a massive number of projects were not able to meet their requisite objectives with just $40 \%$ of the project goals and objectives aligning with the strategy of an organization (PMI, 2014). It becomes more troubling when there is a continuous stress from the top management onto the project/programme managers to reveal the benefits of the project to the sponsoring organization and to the giving to the strategy realization within the projectized organization as per explained by Sulehat \& Taib, (2016).

NGOs working in Pakistan are the main focus of this research as NGOs' governance is quite different from the governance of public entities or private organizations as they do not have single official owner, like the shareholders, investors in for-profit businesses. According to Haq et al. (2019). the managers must have "an almost unmatched degree of autonomy" so these companies/organizations might require some effectual inner governance processes/mechanisms for their administration (Mahmud, Ding \& Hasan, 2019). Hence, this research study has examined the influence of EPG practices followed by the project management of NGO sector development projects on the success of their projects as well as emphasized on the significant role of BRM as a moderator to provide a foundation for project success of future projects under NGOs in Pakistan.

\section{Literature Review and Research Hypothesis}

\subsection{Effective Project Governance and Project Success}

According to (Derakhshan, Turner \& Mancini, 2019), it has been observed that there is a big deviation to recognize and understand the definitions \& practices of effective project governance (EPG) being used in project management 
and further relying on its realistic past settings \& research area of the particular authors as stated by (Bekker, 2015) by creating any lack of agreement on a precise definition of EPG in the existing literature.

McGrath \&Whitty (2015) have explained project governance in a so simple form that it's that system through which we can governed the project, directed the project \& controlled the project. Turner(2020)explained the fact that the role of EPG can be seen in project management practices and in the governance roles for individual as well as for the overall projects for their necessary outcomes. Ul Musawir et al. (2017) illustrate the project governance as a whole "the good value system for projects, assigned responsibilities for projects, necessary processes \& policies for projects which permit the projects to attain those managerial objectives \& goals for projects which is the most important for all the relevant project stakeholders (internal \& external to the organizations).Abednego and Ogunlana (2006) in their study discussed governance and challenges related to governance in the context of Public-Private Partnership (PPP) projects and defined it as "It is the process of problem solving and decision-making through which the right decisions for the projects can be put into operation". Garland (2009) also portray it such as "it's that model/hypothetical framework through which decisions for the project could be made very easily".

Purposefully it's also very important that while doing the configuration of projects, the goals should be the major part of PMI's practice/policies \& necessary guidance to govern the projects /programs \& portfolios. In the same way all the processes/ functions/frameworks which actually provide the guidance for the project management activities for the creation of a unique product/service/result in a very novel way to fulfill organizational goals (PMI, 2016). Moreover "governance of individual projects" \& "governance of group of projects such as portfolio, programs" have the right alignment as for as PMI is concerned (PMI, 2014).EPG offers the systematic approach for tracing as well as communicating the project progress, permitting the project sponsors to comprehend and affect decision making related to project (Bowen et al., 2007). Likewise, Brunet (2016) also recommended EPGin public sector projects permits improved stakeholder management and rational decision making. Zwikael et al. (2015) also determined that effective project governance generates a framework of accountability which ensures that the projects accomplish their business case. For instant, Abednegoet al. (2006) suggested that effective governance helps improving performance of the project by accelerating well-timed efficient allocation of risks risk as well as control over the risks. Furthermore, according to Ma et al. (2020) findings well-definedreceptivegovernancearrangementsareasignificantfactor of success of the projects under Public-PrivatePartnership(PPP).

Though the focus of research has changed to other apprehension of the project team to satisfy customers \&, accomplishment of premeditated objectives of the projects set already, but up till now a lot of project managers are so much anxious/curious about the Project Iron Triangle (Haider \& Kayani, 2020). In addition, the idea of success of project can be even more complicated than a result between failure and success. Examples like the Sydney Opera House signify that if a project is a failure in the context of production efficacy, it can still be successful in the context of investment efficacy (Dvir and Shenhar, 2007). In order to cop up with complication of a success of project, it is compulsory to initially hypothesize it as a multidimensional idea. An amalgamation of previous models in the literature was done by Khan et al (2013), who examined the past forty years of the literature related to the success criteria and created a unified model for measuring the project success.

As for as public sector projects are concerned the "project's efficiency" may precisely be calculated that how efficiently the usage of time and resources would take place by the project team to achieve the desired objectives of the requisite quality parameters (Serrador \& Turner, 2015). As per the definition of "Project Efficiency" given by Dviret al. (2007) "efficiency can only be measured if the project meets the goal of attaining time, cost \& performance", that has been used very frequently as for as the literature regarding project success is concerned in these era (Serrador et al., 2015). The matter of this accomplishment was associated to scope, time \& cost concert that has been classify in the existing literature as micro-success/ short-term success/project management success. The model proposed equilibrium among soft and hard elements and quantifies twenty-four variables of success criteria arranged in following five dimensions: 
1) Project Impact: The project's standing can only be recognized if the project brings those advantages for which it was formed. ul Musawir et al. (2020) distinctly defined the project's outcome in the development of public sector as "the achievements of lasting results from the successful execution/completion of the projects".

2) Stakeholder Satisfaction: The categories for this dimension in the literature include satisfaction of customer, success of the product itself as well as the success of project management. The satisfaction of project's stakeholder was chosen to cover up diverse groups such as "steering committee", "sponsor" \& and "client" of the project.

3) Organizational Benefits: These are those categories which are associate with those benefits which the relevant organization would represent for those completing project remarkably.

4) Future Potential: This factor had items that related to enhancement in capabilities of an organization in order to proceed with future project work, including motivation and learning as well as planning and implementation of project work. As explicated by Dvir et al. (2007) this particular dimension of success actually means, 'Preparing for the Future'.

According to the findings of a study by Clarkson, Pathan, \& Tellam (2016) effectual governance has a very strong/reliable association with the success of projects surrounded by all the factors which are responsible for the success of project. Therefore, it can be concluded that an EPG system can support organizations in not only improving the success of project but also in avoiding the common sources of failure of the project.

Therefore, we have developed the following hypotheses:

H1:EPGpositively associated with future potential (FP).

H2:EPGpositively associated with organizational benefits $(\mathrm{OB})$.

H3:EPGpositively associated with project efficiency (PE).

H4:EPGpositively associated with project impact (PI).

H5:EPGpositively associated with stakeholder satisfaction (SS).

3. Benefits Realization Management as Moderator between Effective Project Governance and Project Success: According to Breese et al. (2015) BRM (benefits realization management) is "a set of processes that ensures that projects, programs, and portfolios embed the requirements of business strategies into business-as-usual, in order to create value in a meaningful and sustainable manner". Chih \& Zwikael, (2015) benefit management is, "Benefits may be objective and quantifiable, such as revenue generation and cost savings, or subjective and unquantifiable, such as customer satisfaction and brand image". Moreover Jenner (2015), targeted paybacks were designated \& framed in the business case of the project for its well-defined agreement by the help of the sponsor of the project. The all targeted benefits were traced/revised \& associated with the necessities of the relevant stakeholders \& sponsors all the way through project life cycle (PMI, 2016). The earlier researches have also transformed the direction to concentrate on organizational potentials for example the ability to be trained \& progress (Svejvig et al., 2020) as well as the capabilities to manage programs (Reiss, 2006) that were required to bring benefits/advantages out of those projects.

In the literature the previous researches had placed the benefit management as a basis of the "Cranfield's Process Model", through which project practices are placed under the "identification, planning, executing and reviewing of some benefits" (Bennington \&Baccarini, 2004) and consumption of other benefits of the projects as well (Ashurst et al., 2008). As per the "Input-Transformation-Output model", the compulsion to acquire benefits is to be selected/nominated to a picky project team member (Zwikael et al., 2015).Major theory behind Thorp's (1998) views regarding the connection between the portfolios, programs and projects is that the task of single projects is to deliver the necessary potentials, is not adequate enough in creation of benefits. Conversely, portfolio management plays a role of maximizing this value throughout the portfolio of the programs (Linhart, Röglinger \& Stelzl, 2020).

Recent researches on project management have extensively encouraged the administrations to concentrate on the understanding of projects benefits (Jenner, 2015; PMI, 2016). Various studies and researches have acknowledged the capacity of good governance as key starter for good benefit management. Similarly, major project management principles have also recognized the role of governance in accelerating benefit management as well as governance 
guidelines such as the "APM's Guide to the Governance of Project Management" (Sirisomboonsuk et al., 2018) and PMBOK of PMI. However, the governance systems that would enable benefit management have not been explored in the previous literature (Hesselmann and Kunal, 2014) hence an in-depth examination is in demand. According to Ahlemann et al., (2013) "Governance system can induce benefits ownership by defining benefits-related goals and by creating incentives for the adoption and implementation of benefit management practices". Also, the top management and leadership can help escort the BRM practices by uninterruptedly keeping the target benefits of project affiliated with the commitments and strategies of the organization (Hjelmbrekke et al., 2014). The point of views mentioned above suggests that EPG is an important factor for effective benefit management. In contrast to that an improper governance structure can result into a key trial for the fruitful execution of benefit management system in the project (Breese et al., 2015).

According to Serra and Kunc (2015) project managers as a result are often put aside from the conversation of benefits management, in spite of the fact that the expertise and support of project manager are vital for efficient BRM (Jenner, 2015; PMI, 2016). Besides, the main argument to BRM implementation is that a major chunk of the establishments yet not realize to apprise project benefits management as a benchmark for the success of a project (Cooke-Davies, 2002).Latest researches on project management excessively advocated the mandatory requirement for the organizations to concentrate on project BRM “(Stretton, 2020;Schlichter, 2020)". Therefore, an effective project governance approach can support in overcoming this hurdle by creating obvious roles \& responsibilities (Mayet al., 2009). The creation of a framework for accountability for the analyzation of advantages/ benefits /planning \& benefit realization (Ahlemann et al., 2013; Badewi, 2015).Hence, it can be theorized that the effect of EPG on project success is due to its improved effect on BRM. Therefore, it is proposed that a moderation relationship is summarized in the following hypotheses of this research:

H6:BRM as moderator between effective EPG and future potential (FP)

H7:BRM as moderator between effective EPG and organizational benefits (OB).

H8:BRM as moderator between effective EPG and project efficiency (PE).

H9:BRM as moderator between effective EPG and project impact (PI).

H10: EPG as moderator between effective EPG and stakeholder satisfaction (SS).

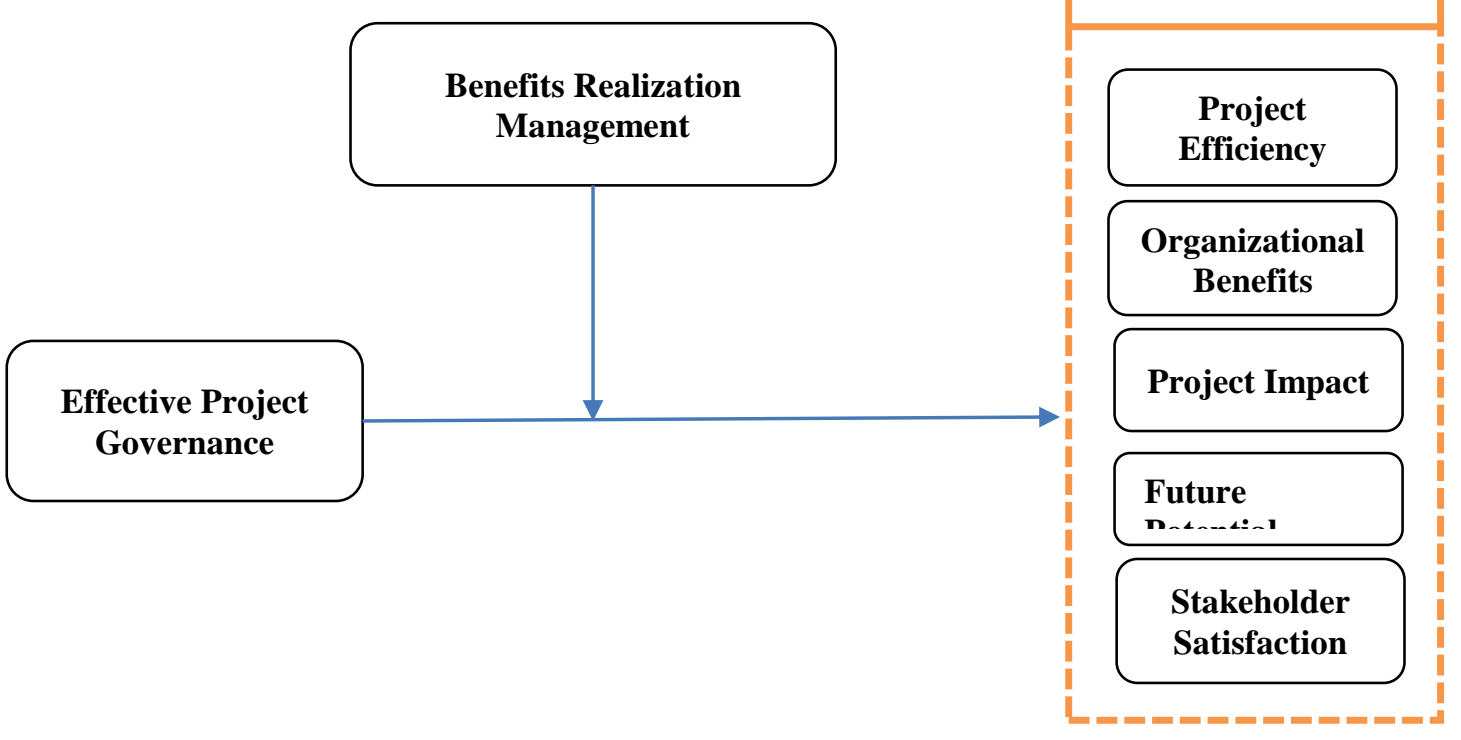

Figure 1: Conceptual Model 


\section{Research Method}

\subsection{Research Design and Sampling Method}

Current research defines exploratory cum descriptive and the research method is naturally attractive. In addition, data collection for all is not possible due to resources and time frames, which is why the sample is used to collect and test data. Therefore, in this study, a simple randomized procedure and data collection was performed over a four-month period (November 2019, February 2020). Possible sampling techniques used to reduce the variance of the standard method from the data collection method (Podsakoff et al., 2003; Fuller et al., 2016). The people of the study consisted of non-governmental organizations (NGOs) namely Islamic Relief Program Director of Pakistan, Helping Hands Relief and Development Pakistan, Muslim Aid Pakistan, Pakistan Red Crescent.

An aggregate of 370 surveys were conveyed the response rate was quite anticipative with whole of 305 useable questionnaires returned, yielding a response rate of $82.43 \%$. The respondents are project assistant, project coordinator, project managerworking in these NGOs. After data collection Harman's single factor test is conducted to identify common method variance the result of extraction sums of squared loading is $27.98 \%$ of variance which is less than 50\%, which means there is no common method biased issue in data (Tehseen, Ramayah \& Sajilan, 2017). Out of these 305 respondents, $49.2 \%$ were male and $50.8 \%$ were female. The majority of the sample fell within the ages of 20-40 years old. With respect to the educational level large numbers of respondents are master's degree holders. Also, the respondents of current study had majority job tenure of 1-3 and 4-6 years.

\section{Measures}

The data was compiled with the help of queries designed from a variety of sources. The questionnaire consisted of a total of 43 items: with respect to independent variables, a 9-item scale developed by Ul Musawir et al. (2017) were used to measure effective project governance (EPG), the dependent variable project success was measured using a 24item scale based on five sub-domains: project efficiency (item 8), organizational benefits (item 4), project impact (item 4), future potential (item 4) and stakeholder satisfaction (item 4) developed by (Joslin, 2015). As a result of managing the effects of benefits realization management (BRM), it was measured using a 10-item scale (Sierra and Kunc, 2015). All items were used on a Likert scale of five points measuring including 1 (Strongly Disagree), 2 (Disagree), 3 (Neutral), 4 (Agree) and 5 (Strongly Agree). It is a very useful tool for data collection because it helps to gather information efficiently and effectively. In order to conduct a more thorough investigation, the pilot study was aimed at ensuring that the questionnaire was valid. Cronbach's alpha was used to check the reliability of the latent variables. Cronbach's alpha for all variables was above the 0.70 thresholds, as reliability above the threshold of 0.7 is considered acceptable (Hensler et al., 2009; Taber, 2018). Cronbach's alpha test results are presented in Table 1.

A multi-component reality-based assessment includes the following tests: factor- loading, variable performance, discriminant validity by the Heterotrait-Monotrait Ratio (HTMT-Ratio) and a moderate/structural model evaluation by predicting the mean value of the prediction $\left(Q^{2}\right)$, variance $\left(R^{2}\right)$ andeffect size $\left(f^{2}\right)$ (Hair et al., 2014).

\subsection{Measurement Model}

The analysis was performed using IBM software and SPSS v. 21 and Smart PLS (Ringle et al., 2015). The first step of the measurement model is being investigated to ensure a list of survey questions that determine the items to be measured, and at the same time to ensure that the tool is reliable. Bootstrapping techniques (T-test 5000 subsample) were used in 305 cases to analyze the significance level of loads, instruments, and road coefficients (Hair et al., 2016). This process consists of load balancing, Cronbach's alpha, Composite Reliability (CR), and Average Variance Extracted (AVE). Furthermore, the validity of the hypothesis of explicit indicators can be assessed by examining specific loads and specific items, where it is suggested that loading, of $>0.50$ on two or more items is shown to be important (Hair et al., 2014). Therefore, the results of the seventh constructs including effective project governance (EPG), future potential (FP), organizational benefits (OB), project efficiency (PE), project impact (PI), stakeholder satisfaction (SS) and benefits realization management (BRM) to the organization are all formal steps for their construction as shown in Table 1. Since, Fornell and Larcker have stated that if AVE is less than 0.5, but combined reliability is higher than 0.6, the flexibility of construction performance is acceptable (Fornell \& Larcker, 1981; Lam, 2012). This approach was suggested by Hair et al. (2014) suggesting that objects with loads elsewhere in the range of 0.40 and 0.70 should be excluded from the measure if the observed variable can increase the combined reliability of the reflective scale. Therefore, after removal, all loading measurements, CR and AVE are larger than the suggested determination process; therefore, Figure 2 shows that the measurement model has a variable performance or 

convergent validity.

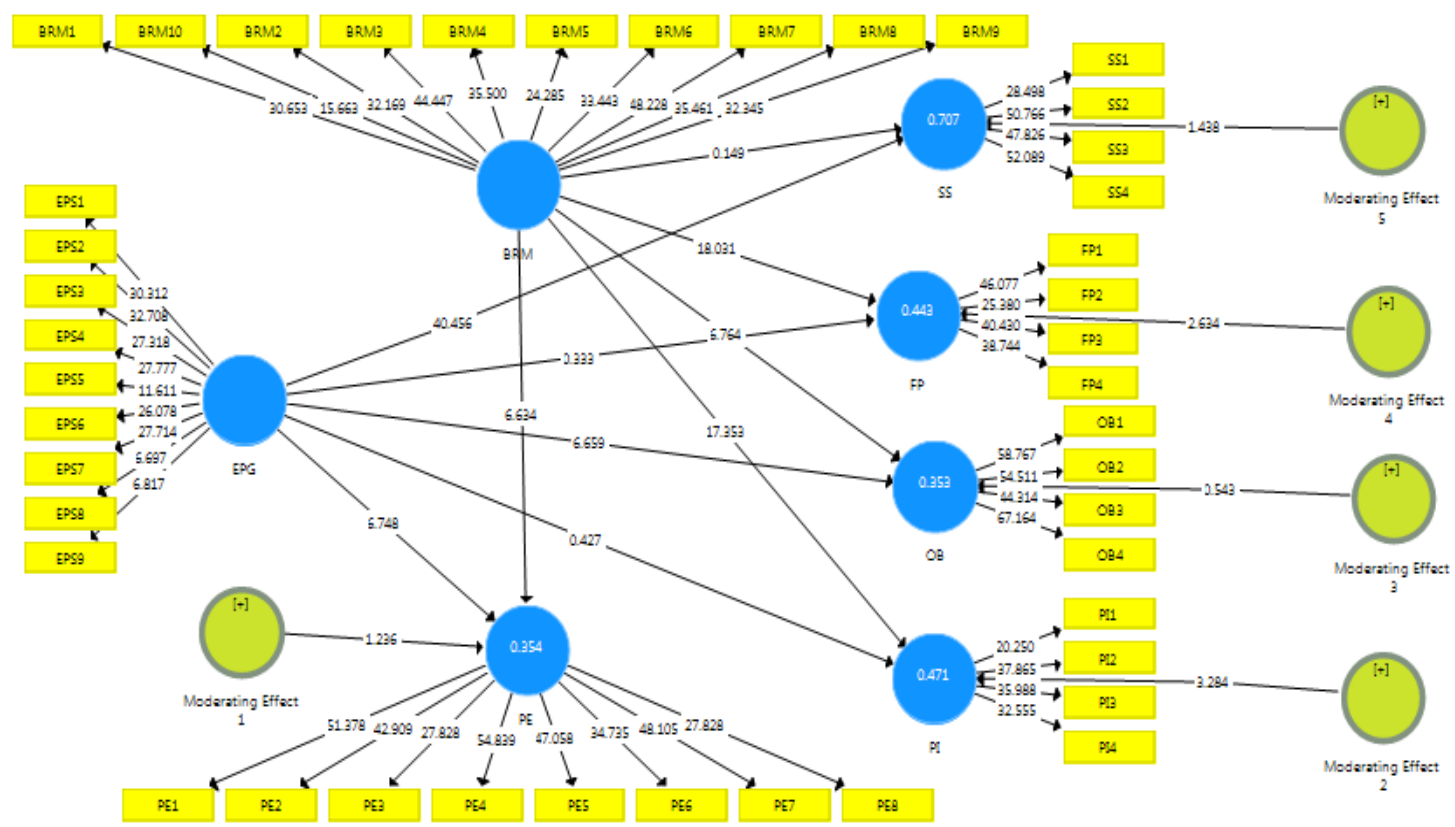

Figure 2: Structural Equation Model

After verifying the flexibility of the model that met the set criteria, the next step was to confirm model bias using the Heterotrait-Monotratit (HTMT) method proposed by Henseler, Ringle and Sarstedt in 2015. There are two methods used by the HTMT method to assess the validity of discrimination. First, using HTMT as a measure involves testing it at a predetermined boundary if the HTMT value is above that threshold and therefore there is no discriminatory performance. The exact threshold value act limit of HTMT is questionable; after all, " when the correlation is close to one". Some researchers raised the limit of 0.85 (Watson et al., 1995; Kline, 2011), while others raised the limit of 0.90 (Gold et al., 2001; Teo et al., 2009). Second, the use of the HTMT inference data analysis when the confidence interval of the HTMT values for the structural pathways contains the value if 1 indicates a lack of discriminatory validity.If the value of 1 fall outside the range of the interval, it proposes that the constructs be empirically distinct.Table 1 shows that the total HTMT value during construction was $<0.85$. As a result, effective bias has been applied to our model.

Table 1: Measurement Model and HTMT Technique

\begin{tabular}{llllllllllll}
\hline \multicolumn{2}{l}{ Constructs } & A & CR & AVE & 1 & 2 & 3 & 4 & 5 & 6 \\
\hline 1. & BRM & 0.915 & 0.929 & 0.569 & & & & & & \\
2. & EPG & 0.850 & 0.886 & 0.476 & 0.414 & & & & & \\
3. & FP & 0.819 & 0.881 & 0.649 & 0.757 & 0.253 & & & & \\
4. & OB & 0.888 & 0.923 & 0.749 & 0.543 & 0.544 & 0.330 & & & \\
5. & PE & 0.930 & 0.942 & 0.672 & 0.520 & 0.537 & 0.363 & 0.794 & & \\
6. & PI & 0.777 & 0.857 & 0.599 & 0.800 & 0.306 & 0.735 & 0.388 & 0.409 & \\
7. & SS & 0.830 & 0.887 & 0.663 & 0.365 & 0.777 & 0.261 & 0.477 & 0.470 & 0.263 \\
\hline
\end{tabular}

Abbreviation: Effective Project Governance (EPG); future potential (FP); organizational benefits (OB); project efficiency (PE); project impact (PI); stakeholder satisfaction (SS); benefits realization management (BRM); Cronbach'sAlpha ( $\alpha$ ); composite reliability (CR) and average variance extracted (AVE).

\section{Structural Equation Model}

The structural measurement model is calculated after the measurement model is made. In this study, the standard bootstrapping method was used to determine the critical levels of any organization during construction. To examine the effects of BRM moderator, we followed the methods recommended by Henseler et al. (2015). To analyze both the direct and indirect effects of the equation model models, using certain specific conditions: First, the $\mathrm{R}^{2}$ value is measured, by the endogenous fluctuations to determine the amount of variation determined by all constructive 
elements (Hair et al., 2016). Although, the satisfactory test of $\mathrm{R}^{2}$ depends on the study setting (Cohen, 1998) shows the test of $0.26,0.13$, and 0.09 showing high, moderate and low, respectively. However, in the current $\mathrm{R}^{2}$ values for endogenous variable, the direct result model describing $\mathrm{FP}=0.443, \mathrm{OB}=0.353, \mathrm{PE}=0.354, \mathrm{PI}=0.471$ and $\mathrm{SS}=0.707$, which means that $44.3 \%$ future potential, $35.3 \%$ organizational benefits, $35.4 \%$ project efficiency, $47.1 \%$ project impactand 70.7 stakeholder satisfaction is predicted by Effective Project Governance through benefits realization management. The model shows sufficient predictive accuracy as shown in Table 2 and Figure 2.

\section{Table 2: Coefficient of Determination in the PLS method}

\begin{tabular}{cccc}
\hline Constructs & R Square & R SquareAdjusted & $\mathbf{Q}^{\mathbf{2}}$ \\
\hline FP & 0.443 & 0.437 & 0.478 \\
OB & 0.353 & 0.346 & 0.431 \\
PE & 0.354 & 0.348 & 0.282 \\
PI & 0.471 & 0.466 & 0.329 \\
SS & 0.707 & 0.704 & 0.342
\end{tabular}

Abbreviation:Future potential (FP); organizational benefits (OB); project efficiency (PE); project impact (PI); stakeholder satisfaction (SS).

Second, determining the significance of the predictable $\left(Q^{2}\right)$ contrast assurance rating was used to measure the value of the probe model estimates (Hair et al., 2014). Table 2 shows the importance of a sufficient estimate of the direct effect model because the $\mathrm{Q}^{2}$ value is greater than zero, $\mathrm{FP}=0.478, \mathrm{OB}=0.431, \mathrm{PE}=0.282, \mathrm{PI}=0.329$ and $\mathrm{SS}=0.342$ for the endogenous latent variable all values greater than zero, it can be considered as an acceptable predictive relevance of the model (Henseler et al., 2015). Results also support the H1, H2, H3, H4 and H5 as presented in Table 3, the direct effect of EPG has significant and positive effect on FP $(\beta=0.182, \mathrm{p}<0.000)$, EPG toOB $(\beta=0.355$, p < $0.000)$, EPG to PE $(\beta=0.359, \mathrm{p}<0.000)$, EPG to PI $(\beta=0.212, \mathrm{p}<0.000)$ and EPG to SS $(\beta=0.833, \mathrm{p}<0.000)$ all were positive and significant.

Third, the size of the effect $\left(\mathrm{f}^{2}\right)$ is the result of a clear independent variation of dependent variables to determine the magnitude of the exogenous (independent variable) effect at the end (dependent variables) (Hair et al. (2014). According to Cohen's law (1988), effect size rated between 0.02, 0.15 and 0.35 as small, medium and medium outcomes, respectively. Table3 specifies the effect size 0.065 of EPG to FP, 0.163 of EPG to OB, 0.167 to EPG to PE, 0.047 to EPG to PI and 1.984 of EPG to SS. The result directs medium and large effect size of these exogenous constructs on the endogenous construct, respectively. Lastly, the model proposes and validate for this study hypothesized that benefits realization management (BRM) would moderate the relationship between Effective Project Governance (EPG) and five sub-dimension of project success (future potential (FP); organizational benefits (OB); project efficiency (PE); project impact (PI); stakeholder satisfaction (SS)). As described in Table 3, the hypotheses $\mathrm{H} 7, \mathrm{H} 8, \mathrm{H} 9$ and H10 were accepted, the moderating effect of BRM on EPG and OB is positive and significant $(\beta=$ $0.296, \mathrm{p}<0.05)$,EPG and PE $(\beta=0.241, \mathrm{p}<0.05)$, EPG and $\mathrm{PI}(\beta=0.228, \mathrm{p}<0.05)$ and EPG and $\mathrm{SS}(\beta=0.23396, \mathrm{p}$ $<0.05)$. However, the moderating effect of BRM on EPG and FP is significant but negatively $(\beta=-0.095, \mathrm{p}<0.05)$, hence hypothesis H6 is rejected.

Table 3: Results of the Structural Equations Model

\begin{tabular}{|c|c|c|c|c|c|c|c|c|}
\hline Hypothesis & $\begin{array}{c}\text { Relationship between } \\
\text { constructs }\end{array}$ & $B$ & Mean & S. D & t Values & $\mathrm{f}^{2}$ & $\mathrm{p}$ Values & Remarks \\
\hline H1 & EPG -> FP & 0.182 & 0.183 & 0.043 & 4.241 & 0.065 & 0.000 & Supported \\
\hline H2 & EPG -> OB & 0.355 & 0.356 & 0.053 & 6.659 & 0.163 & 0.000 & Supported \\
\hline H3 & EPG -> PE & 0.359 & 0.361 & 0.053 & 6.748 & 0.167 & 0.000 & Supported \\
\hline H4 & EPG -> PI & 0.212 & 0.223 & 0.055 & 3.829 & 0.047 & 0.000 & Supported \\
\hline H5 & EPG -> SS & 0.833 & 0.836 & 0.021 & 40.456 & 1.984 & 0.000 & Supported \\
\hline
\end{tabular}


Journal of Accounting and Finance in Emerging Economies

\begin{tabular}{|c|c|c|c|c|c|c|c|c|}
\hline H6 & $\begin{array}{c}\text { Moderating Effect BRM -> } \\
\text { EPG on FP }\end{array}$ & -0.095 & -0.096 & 0.036 & 2.634 & 0.004 & Not \\
Supported
\end{tabular}

Abbreviation: Effective Project Governance (EPG); future potential (FP); organizational benefits (OB); project efficiency (PE); project impact (PI); stakeholder satisfaction (SS); benefits realization management (BRM).

\section{Discussion}

The results and analysis of the data of this study clearly show that there is a (positive) and strong solidity between effective project governance (EPG), benefits realization management (BRM) andsuccess of Non-Governmental Organization (NGO) projects. Ul Musawir et al., 2017 found that there is a strong and positive relationship between EPG and BRM. In addition, the results also show that EPG in project management services has a positive impact on BRM which provides assistance/support in the above-mentioned literature that promotes effective project management support and improved implementation of benefit management processes (Chih et al., 2015; Stretton, 2020) NGO sector. In addition, project management has been found to be in line with project success such as research conducted by perspective the Schlichter, (2020) and U1 Musawir et al. (2020).The EPG has a significant impact on all five-sub dimension of Project success (future potential (FP); organizational benefits (OB); project efficiency (PE); project impact (PI); stakeholder satisfaction (SS).

Moreover, the results also showed that BRM also had a strong and significant impact on OB, PE, PI and SS supporting the results/findings of (Serra \&Kunc, 2015; Badewi, 2016;Svejvig et al., 2020) who obtained similar results in their research that included the effect of BRM on the successful achievement of project objectives and its distinctive magnitude. However, BRM as moderator negatively effect on the relationship between EPG and FP. In addition to those outcomes also contributes to the ongoing discussions and research that compulsory profit management practices are mandatory to achieve project success in terms of implementing strategic objectives to achieve organizational goals with the help of successfully completed projects. BRM has been found to play an essential role in moderator between EPG and project success that demonstrates effective governance that can increase the implementation of profitable management practices so that (Ul Musawir et al., 2017) achieves project success in terms of project benefits.

The results show that the benefit management methods are followed by the project managers of the NGO sector development projects to achieve the short-term and long-term success of the project and all these activities are possible only because of the project management approach followed in the NGO sector projects. Three of these studies are linked and provide an integrated approach to achieving the organization's goals and objectives with regard to the completion of successful projects while keeping their benefits in mind and implementing a profit management approach with the help of a strong and effective project management approach.

\section{Practical Implications of Study}

The most important implication of this research is that non-government organizations (NGOs) are required to be acquainted with that benefit realization \& management both plays an important role in the success of the projects and in order to achieve organizational strategic goals in short as well as long term perspective. Moreover, this study also suggests that project governance plays a significant role in realizing those benefits and enabling them to be taken into consideration during the planning as well as accomplishment phase of the project to achieve project goals by attaining all the project objectives.

Therefore this "integrated approach for projects" could support the implementation of the organizational/managerial strategy/policy through the projects that are being completed successfully with the help of effective project governance Practices and benefits realization management. 


\section{Limitation and Future Direction}

This research study is limited only to the NGO sector development projects in Pakistan. Its results are limited only to the project management staff that practices the project governance over their projects to get success. In future the same model can be studied with the help of qualitative research methodology or with a larger sample size in case of quantitative research to attain a wide variety of results. In addition to the add-on of different external factors, mediator or moderator future research can also exhibit several other dimensions of the variables discussed in this research as well as can analyze the individual effect of the independent variable and the moderator on the individual dimension of project success in order to make it a comparative study.

\section{Conclusion}

The aim of this research study was to study the influences of effective project governance practices on the success factors of the project as well as to study the moderating role of benefit management in achieving project accomplishment via good effective project governance practices. Research related to the influence of benefit management on the success of NGO sector development projects in Pakistan which has also been answered by proving the second hypothesis of this study with the help of the data analysis that indicated a strong relationship between benefit management and project success as well as indicated a significant influence of benefit management on success of the projects in NGOs sector. Research of this study was related to the significant affect of effective project governance on project success factors directly as well as indirectly with the moderating role of benefit management.

\section{References}

Abednego, M. P., \& Ogunlana, S. O. (2006). Good project governance for proper risk allocation in public-private partnerships in Indonesia. International journal of project management, 24(7), 622-634.

Ahlemann, F., Hesselmann, F., Braun, J., \& Mohan, K. (2013). Exploiting Is/it projects' potential-towards a design theory for benefits management. Retrieved from:http://aisel.aisnet.org/ecis2013_cr/210

Ashurst, C., Doherty, N. F., \& Peppard, J. (2008). Improving the impact of IT development projects: the benefits realization capability model. European Journal of Information Systems, 17(4), 352-370.

Badewi, A. (2016). The impact of project management (PM) and benefits management (BM) practices on project success: Towards developing a project benefits governance framework. International Journal of Project Management, 34(4), 761-778.

Bekker, M. C. (2015). Project Governance-the definition and leadership dilemma. Procedia-Social and Behavioral Sciences, 194, 33-43.

Bennington, P., \& Baccarini, D. (2004). Project benefits management in IT projects-An Australian perspective. Project management journal, 35(2), 20-30.

Bowen, P. L., Cheung, M. Y. D., \& Rohde, F. H. (2007). Enhancing IT governance practices: A model and case study of an organization's efforts. international Journal of Accounting information Systems, 8(3), 191-221.

Breese, R., Jenner, S., Serra, C. E. M., \& Thorp, J. (2015). Benefits management: Lost or found in translation. International Journal of Project Management, 33(7), 1438-1451.

Brunet, M., \& Aubry, M. (2016). The three dimensions of a governance framework for major public projects. International Journal of Project Management, 34(8), 1596-1607.

Chih, Y. Y., \& Zwikael, O. (2015). Project benefit management: A conceptual framework of target benefit formulation. International Journal of Project Management, 33(2), 352-362.

Clarkson, P. M., Pathan, S., \& Tellam, A. (2016). Do private equity target firms exhibit less effectual governance structures?. Australian Journal of Management, 41(2), 244-270.

Cohen J. 1988. Statistical Power Analysis for the Behavioral Sciences. New York: Routledge Academic.

Cooke-Davies, T., 2002.The "real” success factors on projects. Int. J. Proj. Manag. 20 (3), 185-190.

Derakhshan, R., Turner, R., \& Mancini, M. (2019). Project governance and stakeholders: a literature review. International Journal of Project Management, 37(1), 98-116.

Fornell C, Larcker DF. Evaluating structural equation models with unobservable variables and measurement error. Journal of Marketing Research, 1981; 18(1), 39-50.

Fuller, C. M., Simmering, M. J., Atinc, G., Atinc, Y., \& Babin, B. J. (2016). Common methods variance detection in business research. Journal of Business Research, 69(8), 3192-3198. 
Garland, R. (2009). Project Governance: A practical guide to effective project decision making. Kogan Page Publishers.

Gold, J. R., Burridge, C. P., \& Turner, T. F. (2001). A modified stepping-stone model of population structure in red drum, Sciaenops ocellatus (Sciaenidae), from the northern Gulf of Mexico. Genetica, 111(1-3), 305-317.

Haider, S. A., \& Kayani, U. N. (2020). The impact of customer knowledge management capability on project performance-mediating role of strategic agility. Journal of Knowledge Management. Retrieved from: https://doi.org/10.1108/JKM-01-2020-0026

Hair Jr, J. F., Sarstedt, M., Hopkins, L., \& Kuppelwieser, V. G. (2014). Partial least squares structural equation modeling (PLS-SEM). European business review.

Hair Jr, J. F., Sarstedt, M., Matthews, L. M., \& Ringle, C. M. (2016). Identifying and treating unobserved heterogeneity with FIMIX-PLS: part I-method. European Business Review.

Haq, S. U., Gu, D., Liang, C., \& Abdullah, I. (2019). Project governance mechanisms and the performance of software development projects: Moderating role of requirements risk. International Journal of Project Management, 37(4), 533-548.

Henseler, J., Ringle, C. M., \& Sarstedt, M. (2015). A new criterion for assessing discriminant validity in variancebased structural equation modeling. Journal of the academy of marketing science, 43(1), 115-135.

Hesselmann, F., \& Kunal, M. (2014). Where are we headed with benefits management research? Current shortcomings and avenues for future research. Retrieved from:

https://aisel.aisnet.org/ecis2014/proceedings/track10/16/

Hjelmbrekke, H., Lædre, O., \& Lohne, J. (2014). The need for a project governance body. International Journal of Managing Projects in Business, 7(4), 661-677.

Jenner, S. (2015). Why do projects 'fail'and more to the point what can we do about it? The case for disciplined, 'fast and frugal'decision-making. Management, 45(2), 6-19.

Joslin, R., \& Müller, R. (2015). Relationships between a project management methodology and project success in different project governance contexts. International journal of project management, 33(6), 1377-1392.

Khan, K., Turner, J. R., \& Maqsood, T. (2013, June). Factors that influence the success of public sector projects in Pakistan. In Proceedings of IRNOP 2013 Conference (pp. 17-19).

Kline, R. B. (2011). Convergence of structural equation modeling and multilevel modeling (pp. Watson, D., Weber, K., Assenheimer, J. S., Clark, L. A., Strauss, M. E., \&McCormick, R. A. (1995). Testing a tripartite model: I. Evaluating the convergent and discriminant validity of anxiety and depression symptom scales. Journal of abnormal psychology, 104(1), 3.

Latif, K., Raza, M. Y., Chaudhary, G. M., \& Arshad, A. (2020). Analysis of Energy Crisis, Energy Security and Potential of Renewable Energy: Evidence from Pakistan. Journal of Accounting and Finance in Emerging Economies, 6(1), 167-182.

Linhart, A., Röglinger, M., \& Stelzl, K. (2020). A project portfolio management approach to tackling the exploration/exploitation trade-off. Business \& Information Systems Engineering, 62(2), 103-119.

Ma, H., Zeng, S., Lin, H., \& Zeng, R. (2020). Impact of Public Sector on Sustainability of Public-Private Partnership Projects. Journal of Construction Engineering and Management, $146(2), 04019104$.

Mahmood, Z., Saba, I., Aamir, M., \& Shah, A. A. (2017). Impact of the Corporate Governance and the Ownership Structure on the Firm Financial Performance and its Risk-Taking Behavior. Journal of Accounting and Finance in Emerging Economies, 3(1), 1-10.

Mahmud, A., Ding, D., \& Hasan, M. M. (2019). Disclosure of Corporate Social Responsibility Practices. Journal of Accounting and Finance in Emerging Economies, 5(2), 295-312.

May, D., Sapountzis, S., Yates, K., Kagioglou, M., \& Aouad, G. (2009). Realising benefits in primary healthcare infrastructures. Facilities. 27 (3/4), 74-87.

McGrath, S. K., \&Whitty, S. J. (2015).Redefining governance: from confusion to certainty and clarity. International Journal of Managing Projects in Business, 8(4), 755-787.

Mir, F. A., \& Pinnington, A. H. (2014). Exploring the value of project management: linking project management performance and project success. International journal of project management, 32(2), 202-217.

PMI, (2014).Pulse of the Profession 2014: The High Cost of low Performance.Project Management Institute.

PMI, (2016). The Strategic Impact of Projects: Identify Benefits to DriveBusiness Results. Project Management Institute.

Podsakoff, P. M., MacKenzie, S. B., Lee, J. Y., \& Podsakoff, N. P. (2003). Common method biases in behavioral 
research: a critical review of the literature and recommended remedies. Journal of applied psychology, 88(5), 879.

Reiss, G., 2006. Handbook of Programme Management. Gower Publishing Company, Limited.

Ringle, C., Da Silva, D., \& Bido, D. (2015). Structural equation modeling with the SmartPLS. Bido, D., da Silva, D., \& Ringle, C.(2014). Structural Equation Modeling with the Smartpls. Brazilian Journal Of Marketing, 13(2).

Santos, C., Santos, V., Tavares, A., \& Varajão, J. (2020). Project Management in Public Health: A Systematic Literature Review on Success Criteria and Factors. Portuguese Journal of Public Health, 38(1), 37-48.

Serra, C. E. M., \& Kunc, M. (2015). Benefits realisation management and its influence on project success and on the execution of business strategies. International Journal of Project Management, 33(1), 53-66.

Serrador, P., \& Turner, R. (2015). The relationship between project success and project efficiency. Project management journal, 46(1), 30-39.

Shenhar, A. J., \& Dvir, D. (2007). Reinventing project management: the diamond approach to successful growth and innovation. Harvard Business Review Press.

Sirisomboonsuk, P., Gu, V. C., Cao, R. Q., \& Burns, J. R. (2018). Relationships between project governance and information technology governance and their impact on project performance. International journal of project management, 36(2), 287-300.

Stretton, A. (2020). Strategic initiatives, project/program management, and responsibilities for benefits realization. PM World Journal, 9.

Sulehat, N. A., \& Taib, C. A. (2016). e-Government Information Systems Interoperability in developing countries: The case of Jordan. Journal of Business and Social Review in Emerging Economies, 2(1), 39-49.

Svejvig, P., \& Schlichter, B. R. (2020). The Long Road to Benefits Management: Toward an Integrative Management Model. Project Management Journal, 51(3), 312-327.

Tehseen, S., Ramayah, T., \& Sajilan, S. (2017). Testing and controlling for common method variance: A review of available methods. Journal of Management Sciences, 4(2), 142-168.

Teo, T. (2009). A case for using structural equation modelling (SEM) in educational technology research. British Journal of educational technology, 41(5), E89-E91.

Tomo, A., Mangia, G., Hinna, A., \& Pellegrini, M. M. (2020). Making collaborative governance effective: a case study on the pathway to successful public-private interactions. International Journal of Public Sector Performance Management, 6(1), 36-55.

Turner, R. (2020). How Does Governance Influence Decision Making on Projects and in Project-Based Organizations?. Project Management Journal, 8756972820939769.

ul Musawir, A., Abd-Karim, S. B., \& Mohd-Danuri, M. S. (2020). Project governance and its role in enabling organizational strategy implementation: A systematic literature review. International Journal of Project Management, 38(1), 1-16.

Ul Musawir, A., Serra, C. E. M., Zwikael, O., \& Ali, I. (2017). Project governance, benefit management, and project success: Towards a framework for supporting organizational strategy implementation. International Journal of Project Management, 35(8), 1658-1672.

Zwikael, O., \& Smyrk, J. (2015). Project governance: Balancing control and trust in dealing with risk. International Journal of Project Management, 33(4), 852-862. 